\title{
Assessment of Factors Affecting Compliance Amongst Patients in Tuberculosis Therapy
}

\author{
Dr Maimona Kanwal MBBS MS Accident \& Emergency ${ }^{1}$, Sana Majeed RN RM Post RN BScN MA English MPH \\ 2 \\ 1. Casualty Medical Officer at Pakistan Institute of Medical Sciences Islamabad, Pakistan. \\ ${ }^{2}$. Nursing Lecturer at Institute of Nursing Wah Medical College, Wah Cantt, Pakistan.
}

DOI: $10.29322 /$ IJSRP.10.06.2020.p10282

http://dx.doi.org/10.29322/IJSRP.10.06.2020.p10282

\begin{abstract}
Objective: To assess the factors affecting the compliance to anti-tuberculosis treatment by identifying the demographic, personal, social and healthcare facility related factors and also identifying the level of awareness amongst the tuberculosis patients about their disease and its dynamics in the public-sector hospital of Islamabad.
\end{abstract}

Study Design: This was descriptive crosssectional study design in the setting of a hospital having significant tuberculosis patient burden. Four hundred and twenty-three patients were included in the study.

Place and Study Duration: It was carried out from patients of Begum Jan Hospital Lehtrar road Islamabad and completed in six-month duration from April 2016 to September 2016.

Materials and Methods: The study was based on well-structured, comprehensive and validated questionnaire. The validity of questionnaire was based on pilot study conducted on ten individuals from sample population. The preliminary questionnaire was modified considering pilot study and then data was collected from TB patients. Data was analyzed by using SPSS version 16.

Results: Study unveiled predominantly middleaged population and females outnumbering male patients. $66 \%$ of study population revealed positive history of tuberculosis contact and $23 \%$ had previous history of tuberculosis and were again coming for therapy. 58\% knew about the common symptoms of tuberculosis and 53\% knew about its infectivity. 37\% knew about its mode of transmission and $38 \%$ did not accepted that coughing, sneezing, shouting and spitting can spread the disease. $40 \%$ study patients were taking medication unsupervised and nearly half of study patients had missed the medication sometime and the dominant causes that lead to missing the dose were nausea, abdominal pain and vomiting. $62 \%$ regarded health being a financial burden. Nearly half were convinced to leave therapy due to side effects of drugs.

Conclusion: The compliance to tuberculosis is the key step in reducing the burden of this communicating disease. Considering the demographics of disease, the personal factors that help to conceptualize the dynamics of Tuberculosis and highlight the importance of its treatment duration are emerging roots of the strategies to decrease the disease prevalence. The meager knowledge about disease treatment strategies, duration of therapy, common symptoms of TB, mode of transmission of TB makes picture more abstract.

Index Terms- Tuberculosis, Antitubercular therapy, Multi-Drug Resistant tuberculosis, Gene expert MultiDrug resistant Tuberculosis/Rifampicin resistant assay.

\section{INTRODUCTION}

$\mathrm{W}$ hile still being part of sustainable development goals to achieve, tuberculosis remains the most challenging of all the diseases to be controlled, treated and eradicated. The bearings of Global milieu are not enough to end the global tuberculosis epidemic (Global Tuberculosis Report 2018, 2018).

Many factors render these global philanthropies ineffective in controlling the tuberculosis epidemic and these factors can be categorized roughly i.e. the factors associated with health systems include lack of access to a health care facility, availability of healthcare service, long waiting hours, ambience of clinic, protracted treatment or liaison between healthcare provider and patient. Social and family characteristics may include the sex of the patient, destitution and the financial burden of treatment, the influence of contemporaries, the preponderance of family and community members and social odium. (Garner, P. 2007).

Mycobacterium tuberculosis is one of the most infectious bactarium that causes tuberculosis. This pathogen not only possess the capability of infecting the lung but also involves extra pulmonary organs. The spread is by airborne particles having size of 1-5 microns in diameter. The pathogenic droplet generates when persons having pulmonary or laryngeal tuberculosis cough, sneeze, shout or sing. It is usually treated with a regimen of drugs taken for 6 months to 
2 years depending on type of infection (Wejse, C. 2008).

First line drugs to treat tuberculosis effectively include isoniazid (INH), rifampin (RIF), pyrazinamide (PZA) and ethambutol (ETH). This first line therapy often fails to treat tuberculosis for many reasons. Firstly, the long regimen, comprising an initial 2 months of intensive phase treatment with all four drugs, followed by the continuation phase for 4 months with INH and RIF. The extensive therapy period with drugs results in a noncompliance leading to treatment failure (Sarkar, S. 2011).

The signs and symptoms of pulmonary tuberculosis include cough of or greater than three weeks, hemoptysis, anorexia, unexplained fever and weight loss and fatigue with findings on chest. The extra pulmonary tuberculosis may exhibit organ specific signs and symptoms like hematuria in case of tuberculosis of kidneys, headache confusion with signs of meningeal irritation in case of tuberculous meningitis, backache in case of pott's disease and unexplained lymphadenopathy of any site. But the unexplained fever and weight loss, fatigue and night sweats are always present in both types of tuberculosis (Wejse, C. 2008).

Globally 1.3 million non-HIV people infected with mycobacterium tuberculosis died, with three hundred thousand deaths amongst HIV carriers. According to global tuberculosis report 2018, the statistics of 2018 reveal the incidence of 10 million worldwide, of which 5.8 million were men, 3.2 million women and 1.0 million children. People living with HIV contributed $9 \%$ of all new tuberculosis cases. $66 \%$ of the new cases were attributed to 8 countries: India, Indonesia, China, Nigeria, Bangladesh, Philippines, Pakistan and South Africa. Multi-drug resistant tuberculosis [MDR-tuberculosis] contributed $3.5 \%$ of new cases and $18 \%$ of old treated tuberculosis whereas extended-drug-resistant tuberculosis [XDRtuberculosis] accounted for $8.5 \%$ of MDRtuberculosis cases. The decline is $3 \%$ per year in tuberculosis related deaths worldwide in HIV positive and $29 \%$ in HIV negative cases. (Global Tuberculosis Report 2018, 2018).

The determinants, that if emphasized at international level can expedite the end tuberculosis strategy of WHO, are the good and accountable governance, engagement of civil community institutes, advocacy for human rights and ethics based on equality with worldwide collaboration. (Global Tuberculosis Report 2015, 2015).

Mortality of HIV plus tuberculosis patients is 1.1 per 100,000 population in Pakistan with HIV negative ones contributing 27 per 100,000 of mortality while India has rate of 31 amongst HIV negative and 0.79 per hundred thousand amongst HIV positive tuberculosis cases. Pakistan being a high tuberculosis burden country had variable statistics during last fifteen years. Being a country fifth in ranking amongst twenty-two high tuberculosis burden countries, the mortality [rate per hundred thousand] excluding the HIV and tuberculosis patients exhibited a declining trend since 2000 whereas incidence [rate per hundred thousand] in case of new and relapse cases depicted gradual rise from 2000 till 2007 afterwards which it becomes steady. The overall incidence has been static since last fifteen years i.e. around 267 per hundred thousand population with prevalence rate of 350 cases per 100,000 population. The treatment success rate for new and relapse cases has been static for last eight to nine years but for MDR/RR-tuberculosis it improved for the years 2008 and 2009 and onwards it also became static. The treatment success rate for XDR tuberculosis has been exhibiting declining trend since 2010. (Global Tuberculosis Report, 2018).

After establishing the roots of decent quality treatment and diagnostics for tuberculosis through DOTS [1994-2005] and stop tuberculosis strategy in high burden countries, the efforts proved promising in reducing the tuberculosis epidemic worldwide. Fortythree million lives were saved. Due to its strong association with poverty and its related factors, tuberculosis persists as a major public health issue. The WHO in 2014 adopted End tuberculosis strategy as a target within health-related Sustainable Development Goal [SDG] 3 in UN sept. 2015 general assembly. The targets set for 2016 to 2035 are specifically directed towards universal health coverage to make high quality tuberculosis treatment accessible equally for all and to ensure the targeted research and development of new tools to prevent tuberculosis aiming to reduce the mortality and incidence by $90-95 \%$. (Floyd, K. 2018).

The end tuberculosis strategy has endorsed a concept of a world free of tuberculosis that conceptualize the reduction in no. of deaths from tuberculosis as compared with 2015 , beginning with $35 \%$ in 2020 to $95 \%$ in 2035 . The reduction in tuberculosis incidence rate is expected or targeted to be $20 \%$ in 2020 to $90 \%$ in 2035 . The unified patient centered care and prevention, audacious policies and complementary systems and deepened research and innovation are the three basic pillars on which the End tuberculosis Strategy will take its stance (Implementing the end tuberculosis strategy: the essentials, 2015).

In Pakistan, joint efforts of Ministry of health, WHO and UNICEF tuberculosis control program helped to establish specialized tuberculosis centers and special tuberculosis wards in DHQ Hospitals, in view of 1962 survey. In 1994 the tuberculosis control strategy was reviewed in collaboration with WHO because of which National policy and technical guidelines were drafted and brought into limelight and 
a highly streamlined national tuberculosis program was prepared. (De Muynck, A. 2001).

Poor housing, poverty, malnutrition and sanitation, inadequate health care facilities, population migration and urbanization, political instability and refugee influx have all continued to aggravate the problem of tuberculosis and DR-tuberculosis. Towards the end century it was realized with consternation by the healthcare professionals that there is a rising incidence of tuberculosis, and in 1994 tuberculosis was declared a Global Emergency by WHO resulting in the formation of the STOP tuberculosis partnership. The aspects of poor or unknown drug quality, inadequate regimens, poor availability of drugs with interrupted supplies, lacking health education, inadequate patient follow-up, poverty and malnutrition, and a lack of a political commitment and resource mobilization have all contributed to the emergence of drug resistant strains of Mycobacteria leading to treatment failures. (Sarkar, S. 2011)

\section{MATERIALS AND METHODS}

This was descriptive cross-sectional study design in the setting of a hospital having significant tuberculosis patient burden. Four hundred and twentythree patients were included in the study.

The research study had been ethically cleared and approved by the research and ethics board of IHMS. The ethical consideration took into account the personal consent form designed for this study, needed to be obtained from the participant. Confidentiality and anonymity were ensured throughout the study as participants were not required to disclose the personal information on questionnaire. Participants were informed that their participation was voluntary, and they may withdraw from the study at any time if they wish to do so. Both male and female TB patients were included from all age groups

\section{RESULT}

The study was conducted on four hundred and twenty-three patients who answered the questionnaires validly.

\section{Knowledge about common symptoms:}

Table 1: whether patient knew about common symptoms of tuberculosis

\begin{tabular}{|l|l|l|}
\hline $\begin{array}{l}\text { Knowledge about } \\
\text { common symptoms of } \\
\text { TB }\end{array}$ & Frequency & Percent \\
\hline Yes & 247 & 58.3924 \\
\hline No & 176 & 41.6075 \\
\hline Total & 423 & 100 \\
\hline
\end{tabular}

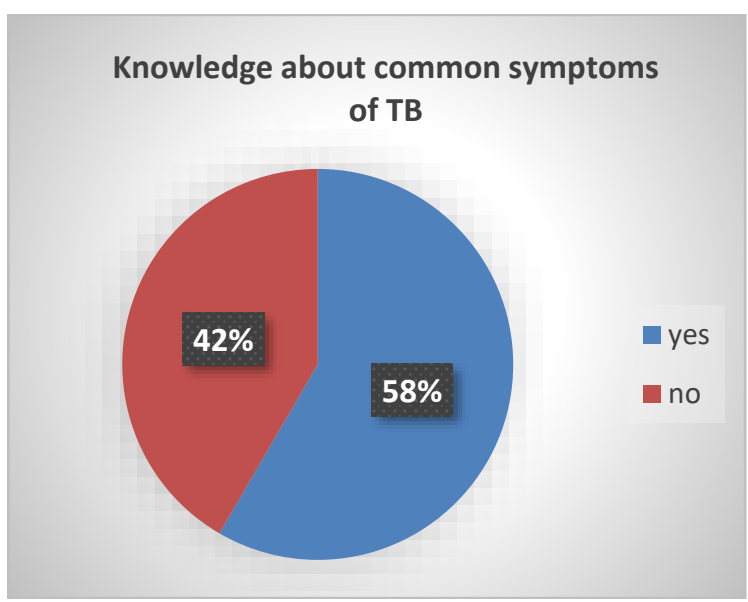

Figure 1: Knowledge about common symptoms of Tuberculosis

$58 \%$ participants had knowledge about common symptoms of tuberculosis (low grade fever, weight loss, anorexia, cough of more than three weeks, night sweats) as compared to $41.6 \%$ who had no knowledge about common symptoms of TB.

\section{Knowledge about transmissibility of TB:}

Table 2: Knowledge about tuberculosis being a transmissible disease

\begin{tabular}{|l|l|l|}
\hline $\begin{array}{l}\text { Knowledge about } \\
\text { tuberculosis being a } \\
\text { transmissible disease }\end{array}$ & $\begin{array}{l}\text { Frequenc } \\
\mathbf{y}\end{array}$ & $\begin{array}{l}\text { Percen } \\
\mathbf{t}\end{array}$ \\
\hline Yes & 226 & 53.427 \\
\hline No & 21 & 4.964 \\
\hline Do not know & 176 & 41.607 \\
\hline Total & 423 & 100 \\
\hline
\end{tabular}




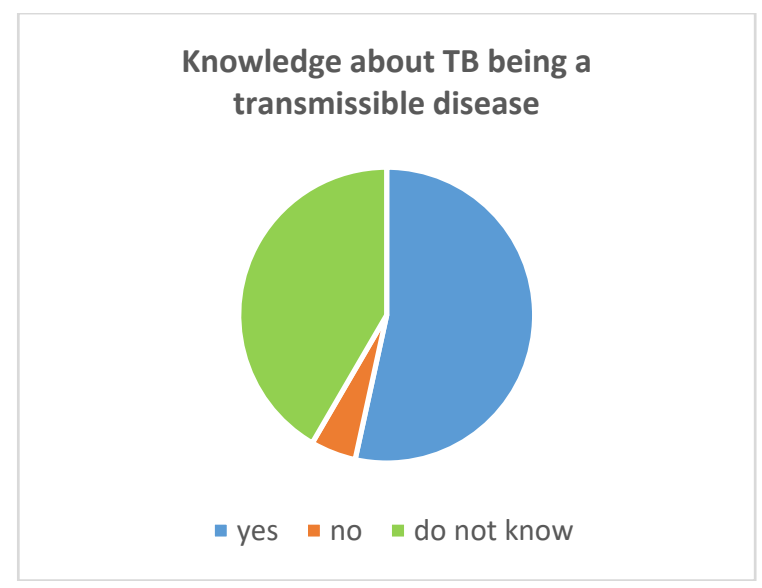

Figure 2: Knowledge about Tuberculosis being a transmissible disease

53.4\% participants knew Tuberculosis as an infective disease whereas $5 \%$ participants considered it to be not an infectious disease and $41.6 \%$ did not knew about Tuberculosis being an infective disease.

Knowledge about preventability of TB:

Table 3: Knowledge about Tuberculosis being a preventable disease

\begin{tabular}{|l|l|l|}
\hline $\begin{array}{l}\text { Knowledge about } \\
\text { tuberculosis being a } \\
\text { preventable disease }\end{array}$ & Frequency & Percent \\
\hline Yes & 406 & 95.981087 \\
\hline No & 17 & 4.0189125 \\
\hline Total & 423 & 100 \\
\hline
\end{tabular}

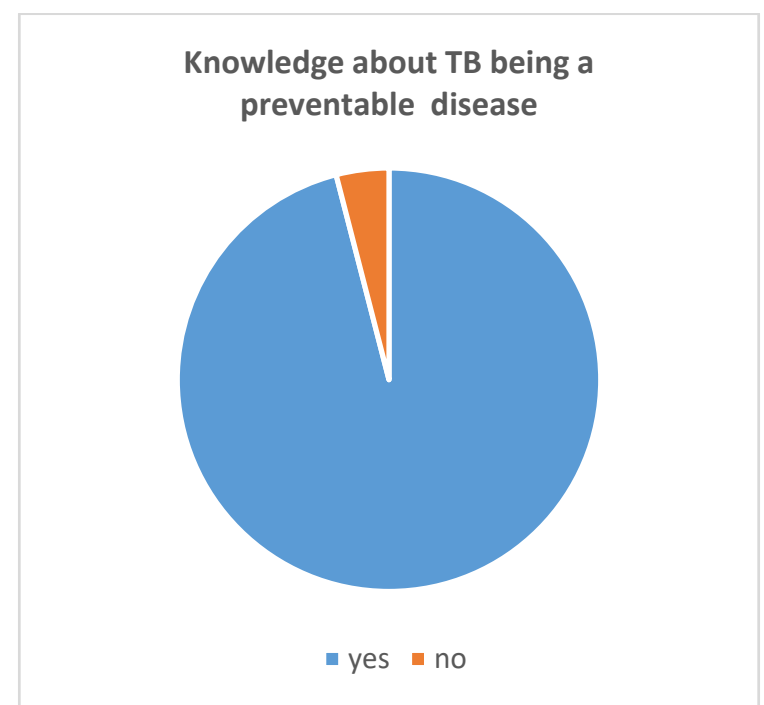

Figure 3: Whether tuberculosis is a preventable disease
96\% participants knew that tuberculosis is a preventable disease whereas only $4 \%$ participant did not know that it is a preventable disease.

Knowledge about treatability of TB:

Table 4: Knowledge about Tuberculosis being a treatable disease

\begin{tabular}{|l|l|l|}
\hline $\begin{array}{l}\text { Knowledge about } \\
\text { tuberculosis being a } \\
\text { treatable disease }\end{array}$ & Frequency & Percent \\
\hline Yes & 354 & 83.6879 \\
\hline No & 42 & 9.9290 \\
\hline Do not know & 27 & 6.38297 \\
\hline Total & 423 & 100 \\
\hline
\end{tabular}

Knowledge about TB being a treatable disease

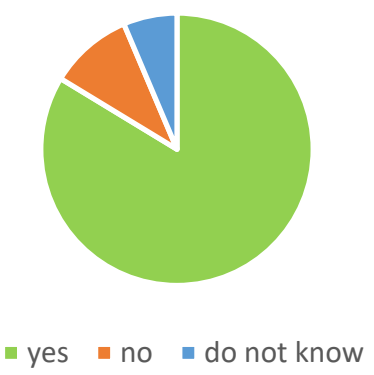

Figure 4: Whether Tuberculosis being a treatable disease

83.6\% participants regarded the Tuberculosis as a treatable disease whereas only $9.9 \%$ participant regarded it as not a treatable disease and $6.4 \%$ did not knew about its status as being treatable disease.

Knowledge about duration of anti-tuberculous drug therapy (ATT):

Table 5: Knowledge about duration of Tuberculosis treatment

\begin{tabular}{|l|l|l|}
\hline $\begin{array}{l}\text { Knowledge about } \\
\text { duration of treatment }\end{array}$ & $\begin{array}{l}\text { Frequenc } \\
\mathbf{y}\end{array}$ & Percent \\
\hline 1 month & 70 & $\begin{array}{l}16.54846 \\
3\end{array}$ \\
\hline
\end{tabular}


ISSN 2250-3153

\begin{tabular}{|l|l|l|}
\hline 2 months & 28 & $\begin{array}{l}6.619385 \\
3\end{array}$ \\
\hline 3 months & 71 & 16.78487 \\
\hline 6 months & 176 & $\begin{array}{l}41.60756 \\
5\end{array}$ \\
\hline 1 year & 78 & $\begin{array}{l}18.43971 \\
6\end{array}$ \\
\hline Total & & 100 \\
\hline
\end{tabular}

\section{Knowledge about duration of treatment}

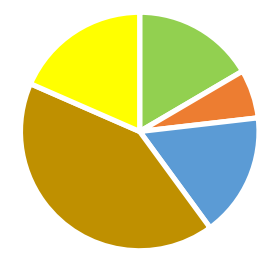

= 1 month $=2$ month $\| 3$ month $\| 6$ month $=1$ year

Figure 5: Knowledge about duration of Tuberculosis treatment

$16.5 \%$ participants thought it only takes one month for the duration of Tuberculosis treatment whereas $6.6 \%$ thought it to be of two months. $16.7 \%$ participants thought it to be of three months whereas $41.6 \%$ identified it to be of six months duration and $18.4 \%$ regarded one year to be the duration of therapy.

Knowledge about possibility of complete recovery after ATT:

Table 6: Knowledge about complete recovery after ATT

\begin{tabular}{|l|l|l|}
\hline $\begin{array}{l}\text { Knowledge about } \\
\text { complete recovery after } \\
\text { ATT }\end{array}$ & Frequency & Percent \\
\hline Yes & 360 & 85.1063 \\
\hline No & 28 & 6.61938 \\
\hline Do not know & 35 & 8.27423 \\
\hline Total & 423 & 100 \\
\hline
\end{tabular}

\section{Knowledge about common symptoms of TB}

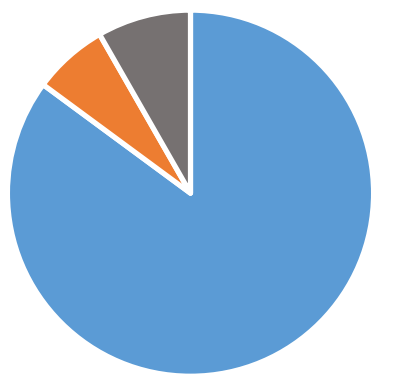

- yes - no - do not know

Figure 6: Does the patient completely recovers after anti-tuberculosis drug therapy

$85 \%$ participants were aware of recovery being complete after ATT whereas $6.6 \%$ regarded the TB being not completely recoverable after ATT and $8.3 \%$ participants did not know about it.

Knowledge about Modes of transmission of TB:

Table 7: Knowledge about transmission routes of TB

\begin{tabular}{|l|l|l|}
\hline $\begin{array}{l}\text { Knowledge about } \\
\text { coughing sneezing } \\
\text { shouting spitting being } \\
\text { the transmission routs } \\
\text { of TB }\end{array}$ & $\begin{array}{l}\text { Frequenc } \\
\text { Percent }\end{array}$ & \\
\hline Yes & 156 & $\begin{array}{l}36.87943 \\
3\end{array}$ \\
\hline No & 162 & $\begin{array}{l}38.29787 \\
2\end{array}$ \\
\hline Do not know & 105 & $\begin{array}{l}24.82269 \\
5\end{array}$ \\
\hline Total & 423 & 100 \\
\hline
\end{tabular}




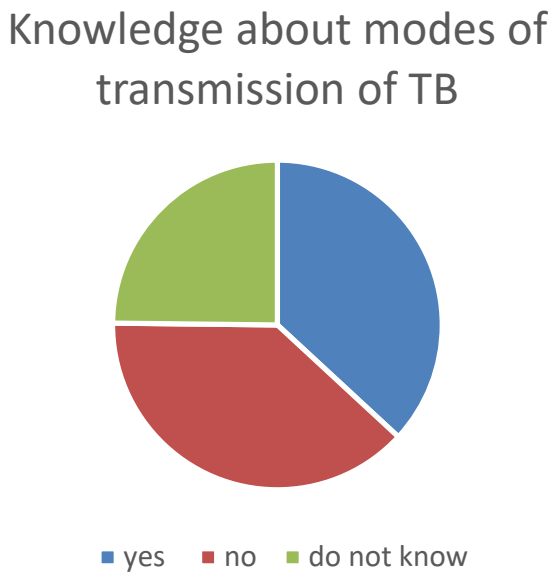

Figure 7: Knowledge about modes of transmission routes of TB

$25 \%$ participants do not know about coughing, sneezing, shouting and spitting being part of routes of transmission that is infectivity of TB whereas only $37 \%$ know that as compared to $38 \%$ participants who do not think coughing sneezing shouting or spitting can cause TB to others.

Knowledge about transmission being preventable:

Table 8: Knowledge of transmission of TB being preventable

\begin{tabular}{|l|l|l|}
\hline $\begin{array}{l}\text { Knowledge of } \\
\text { transmission TB being } \\
\text { preventable }\end{array}$ & Frequency & Percent \\
\hline Yes & 360 & 85.106383 \\
\hline No & 43 & 10.165485 \\
\hline Do not know & 20 & 4.7281324 \\
\hline Total & 423 & 100 \\
\hline
\end{tabular}

\section{Knowledge of transmission being preventable}

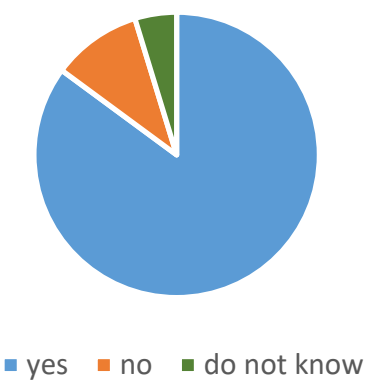

Figure 8: Whether transmission of TB preventable
$85 \%$ participants believed that transmission of TB is preventable whereas $10 \%$ believed that transmission is not preventable and 5\% did not knew about its transmission being preventable.

How participants are taking medication:

Table 9: How the participants were taking their medication

\begin{tabular}{|l|l|l|}
\hline $\begin{array}{l}\text { How participants take } \\
\text { their medication }\end{array}$ & $\begin{array}{l}\text { frequenc } \\
\mathbf{y}\end{array}$ & percent \\
\hline $\begin{array}{l}\text { Under supervision of } \\
\text { family member }\end{array}$ & 240 & $\begin{array}{l}56.73758 \\
9\end{array}$ \\
\hline $\begin{array}{l}\text { Under supervision of } \\
\text { healthcare provider }\end{array}$ & 14 & $\begin{array}{l}3.309692 \\
7\end{array}$ \\
\hline Unsupervised & 169 & $\begin{array}{l}39.95271 \\
9\end{array}$ \\
\hline Total & 423 & 100 \\
\hline
\end{tabular}

\section{How the participant takes} medication

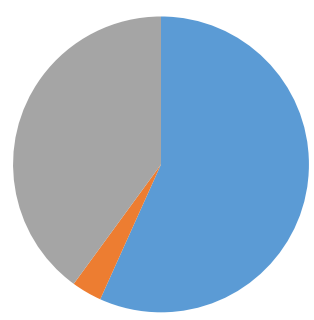

$$
\begin{aligned}
& \text { uder supervision of family member } \\
& \text { under supervision of healthcare provider } \\
& \text { unsupervised }
\end{aligned}
$$

Figure 9: Kind of treatment participants were receiving

$56 \%$ participants were receiving medication under supervision of family members and $3.3 \%$ under healthcare provider's supervision whereas $40 \%$ are taking medication unsupervised.

\section{Participants satisfaction with treatment:}

Table 10: Participant's satisfaction with the treatment

\begin{tabular}{|l|l|l|}
\hline $\begin{array}{l}\text { Participant's } \\
\text { satisfaction with the } \\
\text { treatment }\end{array}$ & Frequency & Percent \\
\hline
\end{tabular}


ISSN 2250-3153

\begin{tabular}{|l|l|l|}
\hline Yes & 387 & 91.489362 \\
\hline No & 36 & 8.5106383 \\
\hline Total & 423 & 100 \\
\hline
\end{tabular}

\section{Participant's satisfaction} with the treatment

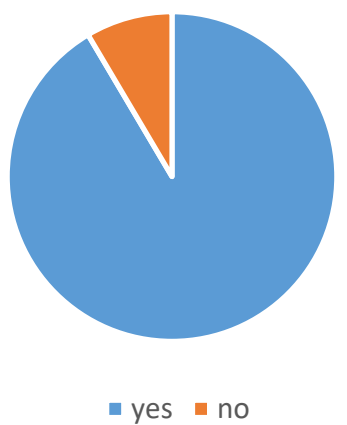

Figure 10: Participant's satisfaction with the treatment

91.5\% participants were satisfied with their treatment whereas $8.5 \%$ participants were not satisfied.

Participants who missed their ATT dose:

Table 11: Participants who ever missed their dose of ATT

\begin{tabular}{|l|l|l|}
\hline $\begin{array}{l}\text { Did participants ever } \\
\text { miss their dose of ATT }\end{array}$ & $\begin{array}{l}\text { Frequenc } \\
\mathbf{y}\end{array}$ & Percent \\
\hline Yes & 197 & $\begin{array}{l}46.57210 \\
4\end{array}$ \\
\hline No & 226 & $\begin{array}{l}53.42789 \\
6\end{array}$ \\
\hline Total & 423 & 100 \\
\hline
\end{tabular}

\section{Did participants ever missed their dose of} medication

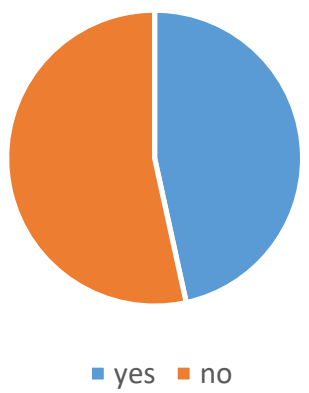

Figure 11: Participants who ever missed their dose of ATT

47\% participants missed their dose of ATT sometime whereas $53.4 \%$ never missed their dose of ATT ever.

Knowledge about development of resistance in case of not following the treatment properly:

Table 12: Participant's knowledge regarding development of resistance in case of not following the treatment properly

\begin{tabular}{|l|l|l|}
\hline $\begin{array}{l}\text { Participant's } \\
\text { knowledge of } \\
\text { resistance } \\
\text { development in case of } \\
\text { not following the } \\
\text { treatment properly }\end{array}$ & $\begin{array}{l}\text { Frequenc } \\
\mathbf{y}\end{array}$ & Percent \\
\hline Yes & 31 & $\begin{array}{l}7.328605 \\
2\end{array}$ \\
\hline No & 392 & $\begin{array}{l}92.67139 \\
5\end{array}$ \\
\hline Total & 423 & 100 \\
\hline
\end{tabular}


Participant's knowledge of resistance development in case of not following the treatment properly

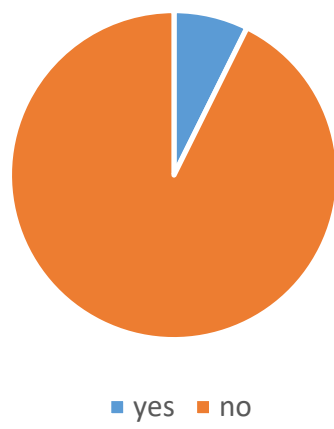

Figure 12: Participant's knowledge of resistance development if treatment is not followed properly

7.3\% participants had knowledge of resistance whereas $93 \%$ participants were not aware of the resistance development in case of treatment being not followed properly.

Knowledge about possibility of life long complications in case of leaving therapy within time course:

Table 13: Do you think to leave therapy within the time course result in long life complications

\begin{tabular}{|l|l|l|}
\hline $\begin{array}{l}\text { Leaving therapy during } \\
\text { its time course will } \\
\text { result in life long } \\
\text { complications }\end{array}$ & $\begin{array}{l}\text { Frequen } \\
\text { cy }\end{array}$ & Percent \\
\hline Yes & 402 & $\begin{array}{l}95.0354 \\
61\end{array}$ \\
\hline No & 21 & $\begin{array}{l}4.96453 \\
9\end{array}$ \\
\hline Total & 423 & 100 \\
\hline
\end{tabular}

Leaving therapy during its time course will result in life long complications

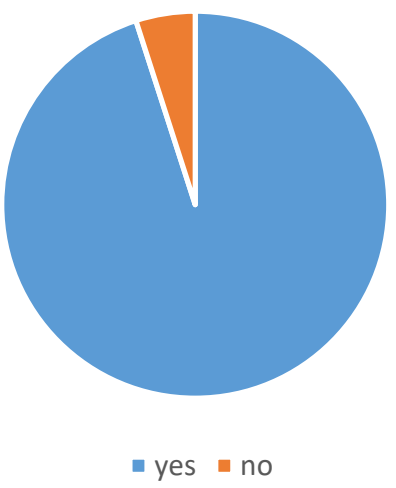

Figure 13: Do you think to leave therapy within the time course result in long life complications

95\% participants accepted that to leave therapy within time course results in long life complications whereas $5 \%$ participants did not.

Symptoms causing missing the dose of ATT:

Table 14: Symptoms causing missing the dose of ATT

\begin{tabular}{|l|l|l|}
\hline $\begin{array}{l}\text { Symptoms causing } \\
\text { missing the ATT dose }\end{array}$ & $\begin{array}{l}\text { Frequenc } \\
\mathbf{y}\end{array}$ & Percent \\
\hline Vomiting & 85 & $\begin{array}{l}20.09456 \\
3\end{array}$ \\
\hline Urine discoloration & 28 & $\begin{array}{l}6.619385 \\
3\end{array}$ \\
\hline Nausea & 113 & $\begin{array}{l}26.71394 \\
8\end{array}$ \\
\hline Abdominal pain & & 26.71394 \\
& 113 & 8 \\
\hline Joint aches & & $\begin{array}{l}16.54846 \\
3\end{array}$ \\
\hline Rashes & 70 & 3.309692 \\
& & 7 \\
\hline Total & 14 & 100 \\
\hline
\end{tabular}


ISSN 2250-3153

Symptoms causing missing the dose of ATT

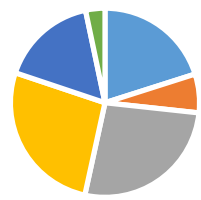

vomiting

- urine discolouration

- nausea

- abdominal pain

- joint aches

Figure 14: Symptoms causing missing the dose of ATT

Vomiting (20\%), nausea $(26.7 \%)$ and abdominal pain $(26.7 \%)$ due to anti-tuberculous drugs remained most prevailing factors causing the missing of ATT dose whereas rashes $(3.3 \% \%)$ and urine discoloration $(6.6 \%)$ as a cause to miss the ATT dose were less dominant with joint aches being prevalent in $16.5 \%$ of study population.

\section{Social features:}

Change in behavior of family members:

Table 15: Change in behavior of family members due to illness

\begin{tabular}{|l|l|l|}
\hline $\begin{array}{l}\text { Change in behavior of } \\
\text { family members due to } \\
\text { illness }\end{array}$ & $\begin{array}{l}\text { Frequenc } \\
\mathbf{y}\end{array}$ & Percent \\
\hline Yes & 94 & $\begin{array}{l}22.22222 \\
2\end{array}$ \\
\hline No & 329 & $\begin{array}{l}77.77777 \\
8\end{array}$ \\
\hline Total & & 100 \\
\hline
\end{tabular}

\section{Change in behavior of family members due to illness}

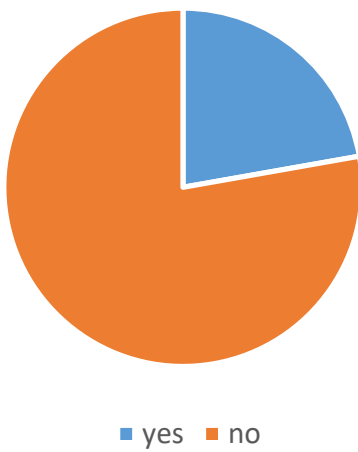

Figure 15: Change in behavior of family members after contracting tuberculosis

Only $22 \%$ participants reported about change in behavior of family members after contracting tuberculosis whereas $77 \%$ observed no change in behavior or attitude of family members.

Fear of loss of employment:

Table 16: Fear of loss of employment due to illness

\begin{tabular}{|c|c|c|}
\hline $\begin{array}{l}\text { Fear of loss of } \\
\text { employment due to } \\
\text { illness }\end{array}$ & $\begin{array}{l}\text { Frequenc } \\
\mathbf{y}\end{array}$ & Percent \\
\hline Yes & 262 & $\begin{array}{l}61.93853 \\
4\end{array}$ \\
\hline No & 59 & $\begin{array}{l}13.94799 \\
1\end{array}$ \\
\hline No employment & 102 & $\begin{array}{l}24.11347 \\
5\end{array}$ \\
\hline Total & 423 & 100 \\
\hline
\end{tabular}




\section{Fear of loss of employment}

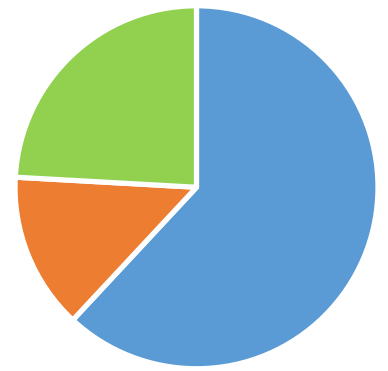

- yes no no employment

Figure 16: Fear of loss of employment due to illness

$62 \%$ participants feared their employments can be lost due to illness whereas $14 \%$ did not as compared to $24 \%$ who had no employment.

\section{Fear of social isolation:}

Table 17: Fear of social isolation in case of people around knows about their illness/due to illness

\begin{tabular}{|l|l|l|}
\hline $\begin{array}{l}\text { Fear of being left } \\
\text { socially isolated due to } \\
\text { illness/after people } \\
\text { around know about } \\
\text { their illness }\end{array}$ & $\begin{array}{l}\text { Frequenc } \\
\mathbf{y}\end{array}$ & Percent \\
\hline Yes & 275 & $\begin{array}{l}65.0118 \\
2\end{array}$ \\
\hline No & 148 & $\begin{array}{l}34.9881 \\
8\end{array}$ \\
\hline Total & 423 & 100 \\
\hline
\end{tabular}

\section{Fear of being left socially isolated after people around know about their illness}

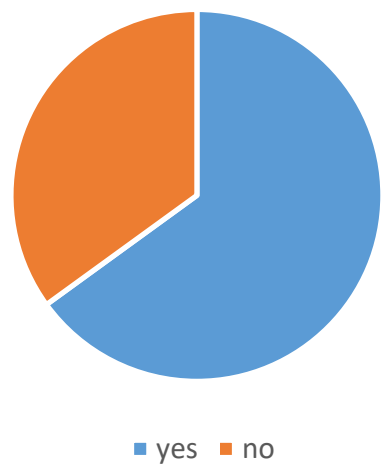

Figure 17: Fear of social isolation due to illness/in case people around know about their disease

$65 \%$ participant feared social isolation in case people around their circle come to know about their disease as compared to $35 \%$ who had no such fear.

\section{Health being a financial burden:}

Table 18: Health being a financial burden for the participants

\begin{tabular}{|l|l|l|}
\hline $\begin{array}{l}\text { Health being a } \\
\text { financial burden for } \\
\text { participants }\end{array}$ & Frequency & Percent \\
\hline Yes & 261 & 61.70212 \\
\hline No & 162 & 38.29787 \\
\hline Total & 423 & 100 \\
\hline
\end{tabular}

\section{Health being a financial burden for participants}

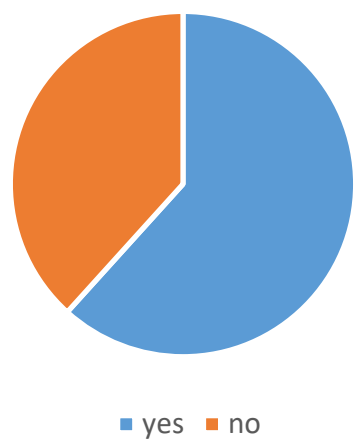

Figure 18: Health being a financial burden for the participants 
ISSN 2250-3153

For $62 \%$ participant's health was a financial burden whereas for $38 \%$ participant's health was not a financial burden.

Participants who got counselling regarding proper way of taking medication:

Table 19: Participants who received counselling regarding medication

\begin{tabular}{|l|l|l|}
\hline $\begin{array}{l}\text { Participants who } \\
\text { received counseling } \\
\text { regarding the proper } \\
\text { way of taking } \\
\text { medication }\end{array}$ & $\begin{array}{l}\text { Frequen } \\
\text { cy }\end{array}$ & Percent \\
\hline Yes & 416 & $\begin{array}{l}98.3451 \\
54\end{array}$ \\
\hline No & 7 & $\begin{array}{l}1.65484 \\
63\end{array}$ \\
\hline Total & 423 & 100 \\
\hline
\end{tabular}

All participants except seven, had received patient counselling regarding use of medication.

Participants receiving counselling regarding the proper way of taking medication

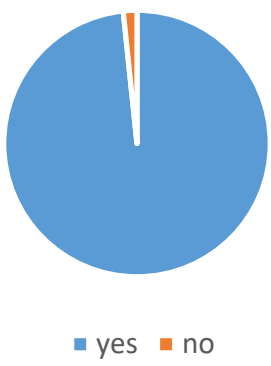

Figure 19: Participants who received counselling regarding proper way of medication

Participants who got counselling regarding side effects of ATT:

Table 20: participants receiving counselling regarding side effects of ATT

\begin{tabular}{|l|l|l|}
\hline $\begin{array}{l}\text { Participants } \\
\text { receiving } \\
\text { counseling } \\
\text { regarding side } \\
\text { effects of ATT }\end{array}$ & Frequency & Percent \\
\hline Yes & 261 & 61.702128 \\
\hline
\end{tabular}

\begin{tabular}{|l|l|l|}
\hline No & 162 & 38.297872 \\
\hline Total & 423 & 100 \\
\hline
\end{tabular}

\section{Participants receiving counselling regarding the side effects of ATT}

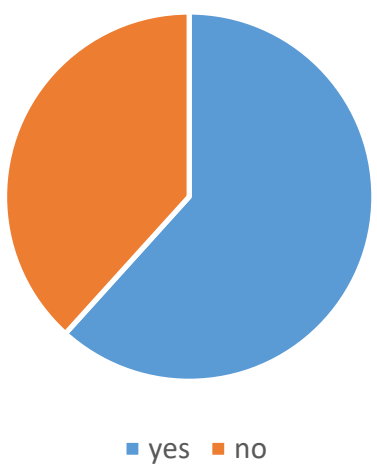

Figure 20: Participants receiving counselling regarding side effects of ATT

$61.7 \%$ participants were aware of side effects of ATT whereas $38.3 \%$ participants had not received counselling about the side effects of ATT.

Table 21: Factors causing participants to think to leave the treatment:

\begin{tabular}{|c|c|c|}
\hline $\begin{array}{l}\text { Factors causing } \\
\text { participants to think to } \\
\text { leave the treatment }\end{array}$ & $\begin{array}{l}\text { Frequenc } \\
\mathbf{y}\end{array}$ & Percent \\
\hline $\begin{array}{l}\text { Long distance of } \\
\text { traveling }\end{array}$ & 35 & $\begin{array}{l}8.274231 \\
7\end{array}$ \\
\hline $\begin{array}{l}\text { Health facility doctor's } \\
\text { availability }\end{array}$ & 7 & $\begin{array}{l}1.654846 \\
3\end{array}$ \\
\hline $\begin{array}{l}\text { Health facility staff's } \\
\text { behavior }\end{array}$ & 17 & $\begin{array}{l}4.018912 \\
5\end{array}$ \\
\hline Severity of side effects & 204 & 48.22695 \\
\hline Inadequate knowledge & 36 & $\begin{array}{l}8.510638 \\
3\end{array}$ \\
\hline $\begin{array}{l}\text { Non-co-operative family } \\
\text { members }\end{array}$ & 46 & $\begin{array}{l}10.87470 \\
4\end{array}$ \\
\hline Long duration of therapy & 78 & $\begin{array}{l}18.43971 \\
6\end{array}$ \\
\hline Total & 423 & 100 \\
\hline
\end{tabular}

$48.2 \%$ participants were convinced to think to leave the treatment due to side effects and $18 \%$ were 
inclined to think so due to long therapy period whereas $11 \%$ participants were thinking so due to noncooperative family members. Health facility staff's behavior and doctor's availability effected only $4 \%$ and $1.65 \%$ of participants to think like that respectively. $8.3 \%$ were compelled to think in that way because of long distances to travel to healthcare facility and inadequate knowledge of the disease made $8.5 \%$ to think so.

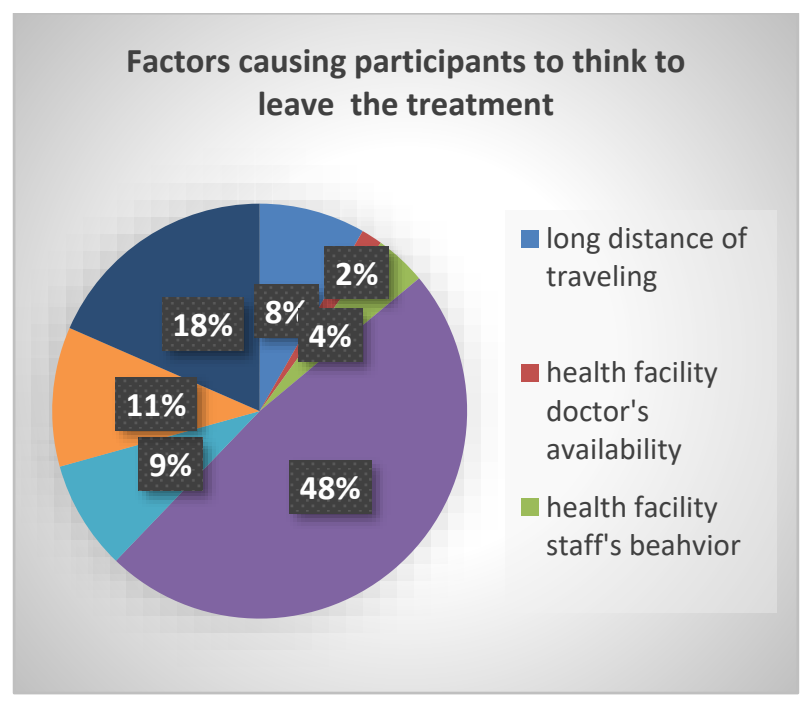

Figure 21: Factors causing the participants to think to leave the treatment

\section{DISCUSSION}

The factors affecting the compliance of TB patients on ATT can largely be classified in four major areas that can be named as health facility related, personal, social, and demographic features. As highlighted in study conducted by Munro, S. A. et al. (2007), the eight features are more pronounced in determining the compliance include health care system, personal knowledge of disease, financial features of treatment, treatment knowledge and beliefs, immigration and laws, personal adherence pattern to treatment, therapeutic adverse reactions and domestic support.

This study also exposed and enunciated the similar areas as under

1. Demographic features like age, gender, marital status, education or literacy level and income.

2. Personal features like history of TB contact, past history, TB being a preventable, transmissible, and treatable disease, awareness about mode of transmission, transmission being preventable, knowledge about common symptoms, duration of treatment, complete recovery after treatment, satisfaction with treatment and lifelong complications.
3. Social features like family members and coworkers being informed, change of behavior of family members and co-workers, colleague's attendance during illness, fear of loss of employment, isolation stigma.

4. Health care facility related features like time and cost to reach the facility, financial attributes of treatment, counselling regarding medication way, counselling regarding side effects of att.

\section{Demographic features:}

The demographics of study population revealed that females outnumbered the males. In contrast to the study conducted by Das, R. et al. (2015) that demonstrated male gender to be associated more with compliance. The study conducted by Bashour, H. et al. (2003) revealed increased compliance and treatment success rate being more associated with female gender. Another study; by Brudney, K and Dobkin, J. (1991) illustrated non-compliance to be more common in males. The middle-aged population predominated in study population consistent with the study by Dye, C. et al. (2008). Married participants dominated this study.

\section{Personal features:}

More than $66 \%$ of study population had positive history of $\mathrm{TB}$ contact enunciating the importance of knowledge about infectivity of disease. A study by OBoyle, S. et al. (2002) highlights that having a member with TB in family of patient with TB made TB patients prone to leave the therapy once the symptoms settle and DOTS can be made successful once more knowledge is imparted to the TB patients. Only $23 \%$ had past history of tuberculosis whereas $76 \%$ had no past history of TB; but those with past history of TB means they had TB previously and they were again coming for it, highlighting the fact that poor compliance either due to improper prescriptions by physicians or due to partially treated cases (Khan, J. A. et al., 2003) or due to inappropriate treatment (Liang, L. et al., 2012) has the potential to give rise to MDR-TB cases (Khan, J. A. et al., 2003).

Thirty seven percent of the study population believed that coughing, sneezing, shouting and spitting can spread the illness and $38 \%$ did not accepted this phenomenon and rest of study group did not knew about it. On the other hand, maximum knew that spread of TB is preventable.

More than eighty five percent subjects were assured of complete recovery after treatment, but few did not either knew or were not assured of complete recovery of disease after therapy. Most of study population subjects were taking medication under family or kin's supervision whereas $40 \%$ were taking the medication unsupervised and very few were taking medication supervised by healthcare provider. Das, R. 
et al. (2015) determined that supervised treatment in continuation phase increases the compliance.

\section{Social features:}

Almost all participants had informed their family members about their disease with only $22 \%$ of study population who found altered behaviors of their kin. Also, majority had informed their co-workers and majority being visited by their friends and colleagues with all participants being observant of changed behaviors of their co-workers.

Meulemans, H. et al. (2002) revealed social stigmatization increases the chances of noncompliance also Liefooghe, R. et al. (1995) revealed $\mathrm{TB}$, if regarded as social odium, nurture the loss of relationships and increases the dependency on family socially and financially culminating in denial of diagnosis and treatment in fear of being socially, morally and financially rejected. According to study by Rubel, A. J. and Garro, L.C. (1992), health culture and social odium has strong impact in determining the compliant behavior.

\section{Healthcare facility related features:}

The participants who were cognizant of long distance of travelling to healthcare facility were $35 \%$ of study group as compared to the rest who were not. According to study by Naing, N. N. et al. (2001) noncompliant patients have their homes away from health facility also study by Brasil, P.E.A.A.D. and Braga, J. U. (2008) identified the difficult access to health services as determining factor for non-compliance.

\section{Factors accounting to make participant to think to} leave the treatment:

Nearly half of them recognized side effects of drugs may convince them to leave treatment whereas $11 \%$

The bounteous no of patients un-supervised for medication intake leaves a large vulnerable group who can easily adopt noncompliant strategy. The perceivable cases with positive TB contact and macroscopic ones with past positive history of TB, give prominence to the need to explore the TB population. The distinguishable factors like side effects of drugs, social stigmata associated with disease, counseling related to side effects of therapy and treatment strategy are evident that need to be worked on.

\section{RECOMMENDATIONS}

1. Health education related to TB disease transmissibility, modes of transmission, importance of long duration of therapy and importance of completing the course of treatment are in need to be implemented to expedite the compliance at patient's level.

2. Health advocacy of preventive measures to reduce the disease spread and measures to reduce side effects and strategies to cope with side effects should be highlighted at patient's and general population level both agreed to hold non-cooperative family members responsible to make them think to leave treatment. Pachi, A. et al. (2013) studied the relationship of side effects of ATT with development of psychiatric comorbidities like depression leading to noncompliance. Some voted for long travelling distance and inadequate knowledge and very few regarded doctor's availability and staff's behavior compelling them to leave treatment.

Skeptical thinking about disease, diagnosis and treatment; economics related issues, personal job or study related factors, drug side effects, psychiatric and health facility related factors play vital role in determining the compliance according to Ito, K. et al. (2008). Lack of health insurance, homelessness, physical barriers to medicine use and drug adverse reactions determine non-compliance according to study by Craig, G. M. et al. (2015)

\section{CONCLUSION}

The compliance to tuberculosis is the key step in reducing the burden of this communicating disease. Considering the demographics of disease, the personal factors that help to conceptualize the dynamics of Tuberculosis and highlight the importance of its treatment duration are emerging roots of the strategies to decrease the disease prevalence. The meager knowledge about disease treatment strategies, duration of therapy, common symptoms of $\mathrm{TB}$, mode of transmission of TB makes picture more abstract.

3. Health education of general population to raise an awareness of tuberculosis and to remove the social odium of disease with measures to help and accept the tuberculosis patient can help to increase the compliance. Health education at healthcare provider level to stick to treatment guidelines and to provide adequate counseling and knowledge of disease to patient and patient's relatives can positively impact the compliance.

\section{REFERENCES}

[1] Ahmed, M., Fatmi, Z., Ali, S., Ahmed, J., \& Ara, N. (2009). Knowledge, attitude and practice of private practitioners regarding TB-DOTS in a rural district of Sindh, Pakistan. J Ayub Med Coll Abbottabad, 21(1), 28-31.

[2] Bashour, H., \& Mamaree, F. (2003). Gender differences and tuberculosis in the Syrian Arab Republic: patients' attitudes, compliance and outcomes.

[3] Bassili, A., Seita, A., Baghdadi, S., AlAbsi, A., Abdilai, I., Agboatwalla, M., ... \& Enarson, D. A. (2008). Diagnostic and treatment delay in tuberculosis in 7 countries of the Eastern Mediterranean Region. Infectious Diseases in Clinical Practice, 16(1), 23-35.

[4] Brasil, P. E. A. A. D., \& Braga, J. U. (2008). Meta-analysis of factors related to health services that predict treatment default by tuberculosis patients. Cadernos de Saude Publica, 24, s485-s502. 
[5] Brudney, K., \& Dobkin, J. (1991). Resurgent tuberculosis in New York City: human immunodeficiency virus, homelessness, and the decline of tuberculosis control programs. American Review of Respiratory Disease, 144(4), 745-749.

[6] Butt, T., Ahmad, R. N., Kazmi, S. Y., \& Rafi, N. (2004). Multi-drug resistant tuberculosis in Northern Pakistan. Journal-Pakistan Medical Association, 54, 469-471.

[7] Centers for Disease Control and Prevention (CDC). (2003). Division of Tuberculosis Elimination. Core curriculum on tuberculosis: what the clinician should know, 2000. Atlanta, USA, Updated August.

[8] Craig, G. M., \& Zumla, A. (2015). The social context of tuberculosis treatment in urban risk groups in the United Kingdom: a qualitative interview study. International Journal of Infectious Diseases, 32, 105-110.

[9] Das, R., Baidya, S., Das, J. C., \& Kumar, S. (2015). A study of adherence to DOTS regimen among pulmonary tuberculosis patients in West Tripura District. Indian Journal of Tuberculosis, 62(2), 74-79.

[10] De Muynck, A., Siddiqi, S., Ghaffar, A., \& Sadiq, H. (2001). Tuberculosis control in Pakistan: critical analysis of its implementation. J Pak Med Assoc, 51(1), 41-7.

[11] Dye, C., \& Williams, B. G. (2008). Eliminating human tuberculosis in the twenty-first century. Journal of the Royal Society Interface, 5(23), 653-662.

[12] Enarson, D. A., \& Billo, N. E. (2007). Critical evaluation of the global DOTS expansion plan. Bulletin of the World Health Organization, 85(5), 395-398.

[13] Floyd, K., Glaziou, P., Zumla, A., \& Raviglione, M. (2018). The global tuberculosis epidemic and progress in care, prevention, and research: an overview in year 3 of the End TB era. The Lancet Respiratory Medicine, 6(4), 299-314.

[14] Garner, P., Smith, H., Munro, S., \& Volmink, J. (2007). Promoting adherence to tuberculosis treatment. Bulletin of the World Health Organization, 85(5), 404-406.

[15] Holtz, T. H., Lancaster, J., Laserson, K. F., Wells, C. D., Thorpe, L., \& Weyer, K. (2006). Risk factors associated with default from multidrugresistant tuberculosis treatment, South Africa, 1999-2001. The International Journal of Tuberculosis and Lung Disease, 10(6), 649-655.

[16] Husain, M. O., Dearman, S. P., Chaudhry, I. B., Rizvi, N., \& Waheed, W. (2008). The relationship between anxiety, depression and illness perception in tuberculosis patients in Pakistan. Clinical Practice and Epidemiology in Mental Health, 4(1), 1

[17] Ito, K., Yoshiyama, T., Nagata, Y., Kobayashi, N., Kato, S., \& Ishikawa, N. (2008). What is needed to prevent defaulting from tuberculosis treatment? Kekkaku: [Tuberculosis], 83(9), 621-628.

[18] Kaona, F. A., Tuba, M., Siziya, S., \& Sikaona, L. (2004). An assessment of factors contributing to treatment adherence and knowledge of $\mathrm{TB}$ transmission among patients on TB treatment. BMC Public health, 4(1), 1.

[19] Khan, A., Walley, J., Newell, J., \& Imdad, N. (2000). Tuberculosis in Pakistan: socio-cultural constraints and opportunities in treatment. Social Science \& Medicine, 50(2), 247-254.

[20] Khan, J. A., \& Hussain, S. F. (2003). Anti-tuberculous drug prescribing: doctors' compliance at a private teaching hospital in Pakistan. Tropical doctor, 33(2), 94-96.

[21] Khan, J. A., \& Malik, A. (2003). Tuberculosis in Pakistan: are we losing the battle? JOURNAL-PAKISTAN MEDICAL ASSOCIATION, 53(8), 320-320.

[22] Khan, M. A., Walley, J. D., Witter, S. N., Shah, S. K., \& Javeed, S. (2005). Tuberculosis patient adherence to direct observation: results of a social study in Pakistan. Health policy and planning, 20(6), 354-365.

[23] Liefooghe, R., Michiels, N., Habib, S., Moran, M. B., \& De Muynck, A. (1995). Perception and social consequences of tuberculosis: a focus group study of tuberculosis patients in Sialkot, Pakistan. Social Science \& Medicine, 41(12), 1685-1692.

[24] Liefooghe, R., \& Muynck, A. D. (2001). The dynamics of tuberculosis treatment adherence. JOURNAL-PAKISTAN MEDICAL ASSOCIATION, 51(1), 3-9.

[25] Liefooghe, R., Suetens, C., Meulemans, H., Moran, M. B., \& De Muynck, A (1999). A randomised trial of the impact of counselling on treatment adherence of tuberculosis patients in Sialkot, Pakistan. The International Journal of Tuberculosis and Lung Disease, 3(12), 1073-1080.

[26] Liam, C. K., Lim, K. H., Wong, C. M. M., \& Tang, B. G. (1999). Attitudes and knowledge of newly diagnosed tuberculosis patients regarding the disease, and factors affecting treatment compliance. The International Journal of Tuberculosis and Lung Disease, 3(4), 300-309.
[27] Liang, L., Wu, Q., Gao, L., Hao, Y., Liu, C., Xie, Y., ... \& Fang, H. (2012). Factors contributing to the high prevalence of multidrug-resistant tuberculosis: a study from China. Thorax, 67(7), 632-638.

[28] Menzies, R., Rocher, I., \& Vissandjee, B. (1993). Factors associated with compliance in treatment of tuberculosis. Tubercle and Lung Disease, 74(1), 32-37.

[29] Merza, M. A., Farnia, P., Tabarsi, P., Khazampour, M., Masjedi, M. R., \& Velayati, A. A. (2011). Anti-tuberculosis drug resistance and associated risk factors in a tertiary level TB center in Iran: a retrospective analysis. The Journal of Infection in Developing Countries, 5(07), 511-519.

[30] Meulemans, H., Mortelmans, D., Liefooghe, R., Mertens, P., Zaidi, S. A. Solangi, M. F., \& De Muynck, A. (2002). The limits to patient compliance with directly observed therapy for tuberculosis: a socio-medical study in Pakistan. The International journal of health planning and management, 17(3), 249-267.

[31] Morsy, A. M., Zaher, H. H., Hassan, M. H., \& Shouman, A. (2003) Predictors of treatment failure among tuberculosis patients under DOTS strategy in Egypt.

[32] Munro, S. A., Lewin, S. A., Smith, H. J., Engel, M. E., Fretheim, A., \& Volmink, J. (2007). Patient adherence to tuberculosis treatment: a systematic review of qualitative research. PLoS Med, 4(7), e238.

[33] Mushtaq, M. U., Majrooh, M. A., Ahmad, W., Rizwan, M., Luqman, M. Q., Aslam, M. J., ... \& Shad, M. A. (2010). Knowledge, attitudes and practices regarding tuberculosis in two districts of Punjab, Pakistan. The international journal of tuberculosis and lung disease, 14(3), 303-310.

[34] Naing, N. N., D'Este, C., Isa, A. R., Salleh, R., Bakar, N., \& Mahmod, M. R. (2001). Factors contributing to poor compliance with anti-TB treatment among tuberculosis patients.

[35] Nuwaha, F. (1997). Factors influencing completion of treatment among tuberculosis patients in Mbarara District, Uganda. East African medical journal, 74(11), 690-693.

[36] OBoyle, S., Power, J., Ibrahim, M. Y., \& Watson, J. (2002). Factors affecting patient compliance with anti-tuberculosis chemotherapy using the directly observed treatment, short-course strategy (DOTS). The International Journal of Tuberculosis and Lung Disease, 6(4), 307-312.

[37] Pachi, A., Bratis, D., Moussas, G., \& Tselebis, A. (2013). Psychiatric morbidity and other factors affecting treatment adherence in pulmonary tuberculosis patients. Tuberculosis research and treatment, 2013.

[38] Raviglione, M., \& Director, G. T. (2013). Global strategy and targets for tuberculosis prevention, care and control after 2015. World Health Organization, Geneva.

[39] Rubel, A. J., \& Garro, L. C. (1992). Social and cultural factors in the successful control of tuberculosis. Public health reports, 107(6), 626.

[40] Sarkar, S., \& Suresh, M. R. (2011). An overview of tuberculosis chemotherapy-a literature review. Journal of Pharmacy \& Pharmaceutical Sciences, 14(2), 148-161.

[41] Sloan, J. P., \& Sloan, M. C. (1981). An assessment of default and noncompliance in tuberculosis control in Pakistan. Transactions of the Royal Society of Tropical Medicine and Hygiene, 75(5), 717-718.

[42] Sudore, R. L., Mehta, K. M., Simonsick, E. M., Harris, T. B., Newman, A B., Satterfield, S., ... \& Yaffe, K. (2006). Limited literacy in older people and disparities in health and healthcare access. Journal of the American Geriatrics Society, 54(5), 770-776.

[43] Tanimura, T., Jaramillo, E., Weil, D., Raviglione, M., \& Lönnroth, K. (2014) Financial burden for tuberculosis patients in low-and middle-income countries: a systematic review. European Respiratory Journal, 43(6), 1763 1775 .

[44] Vermund, S. H., Altaf, A., Samo, R. N., Khanani, R., Baloch, N., Qadeer, E., $\&$ Shah, S. A. (2009). Tuberculosis in Pakistan: A decade of progress, a future of challenge. J Pak Med Assoc, 59(4), 1-8.

[45] Wejse, C., Gustafson, P., Nielsen, J., Gomes, V. F., Aaby, P., Andersen, P. L., \& Sodemann, M. (2008). TB score: Signs and symptoms from tuberculosis patients in a low-resource setting have predictive value and may be used to assess clinical course. Scandinavian journal of infectious diseases, 40(2), 111-120.

[46] World Health Organization. (2018). Global tuberculosis report 2018.

[47] World Health Organization. (2015). Global tuberculosis report 2015.

[48] World Health Organization. (2016). Global tuberculosis report 2016. 
[49] World Health Organization. (2008). Global tuberculosis control: surveillance, planning, financing: WHO report 2008(Vol. 393).

[50] World Health Organization. (2015). Implementing the end TB strategy: the essentials (No. WHO/HTM/TB/2015.31).

[51] World Health Organization. (2009). WHO policy on TB infection control in health-care facilities, congregate settings and households (No. WHO/HTM/TB/2009.419).

\section{AUTHORS}

First Author - Dr Maimona Kanwal MBBS MS Accident \& Emergency, Casualty Medical Officer at Pakistan Institute of Medical Sciences Islamabad, Pakistan.

Second Author - Sana Majeed RN RM Post RN BScN MA English MPH, Nursing Lecturer at Institute of Nursing Wah Medical College, Wah Cantt, Pakistan. 